\title{
Treatment of Ulnar Neuritis and early Ulnar Paralysis
}

\author{
E. P. VAIDYANATHAN, M.B.B.s. \\ Medical Officer \\ Mrs. S. I. VAIDYANATHAN, м.B.B.s., D.т.м. \& H. \\ Medical Officer \\ Leprosy Centre, Polambakkam, Madras, S. India
}

In the last 2 decades, reconstructive surgery for the deformities associated with leprosy has come into its own. However, surgery can rarely restore full range of movement or bring back lost sensation. In spite of sulphones and other anti-leprosy drugs, neuritis sometimes supervenes, with resulting deformities and trophic ulceration.

Many workers have tried to relieve the pain of ulnar neuritis with drugs, and others have attempted different surgical procedures with the same intention. Various operative techniques are described such as: external neurolysis, neurolysis combined with longitudinal incision of the epineurium, endoneurolysis and fascicular neurolysis.

Most of the serious disabilities occurring in leprosy are the consequence of damage to mixed nerve trunks. Such damage is usually associated with swelling of the nerve, and secondary ischaemia may be the immediate factor causing damage by compression.

The surgical procedure of choice at the Leprosy Centre, Polambakkam, is external neurolysis. The patients were selected at random. Those with bilateral neuritis (mostly acute), those whose nerves were less enlarged or with hands with slight degrees of paresis or paralysis were kept as controls, as were also some others with unilateral neuritis.

Full records were kept of duration of pain, sensory charting (with nylon No. 5), motor power of muscles, and the patients' own statements concerning ability to work; all these were noted before and after treatment.
The operative technique was as follows (Figs. 1 to 3): An incision of about 3 inches was made over the ulnar groove. After dissection of the superficial tissues, the ulnar nerve was identified and its fascial roof divided. The dissection was continued distally to the point where the nerve dips between the 2 heads of the flexor carpi ulnaris. The fibrous arch was divided completely, and then excised in order to prevent further adhesions. No tourniquet was used, and care was taken not to infiltrate the nerve or to incise its sheath. The following observations were made at operation: The nerves were enlarged proximal to the arch and compressed at the arch itself. The arch was thickened. The nerve was white proximally, but distal to the arch it was yellowish. Shortly after decompression, the vasa nervorum on the antero-lateral aspect of the nerve could be seen filling up. The patient volunteered that he experienced relief of pain soon after division of the fibrous arch.

After the operation, the paralysed hands were immobilised in the lumbrical position for 3 to 4 weeks. After the removal of plaster, massage and exercise of the hands were encouraged. Tables 1 and 2 give the analysis of the treatment and control groups.

\section{RESULTS}

Neuritis (Table 3). Forty patients in whom the nerve was compressed after a short period of fibrous constriction, had no recurrence; out of 45 patients in whom the constriction was of long duration, 43 had no recurrence. Table 4 gives the corresponding results for the controls. 


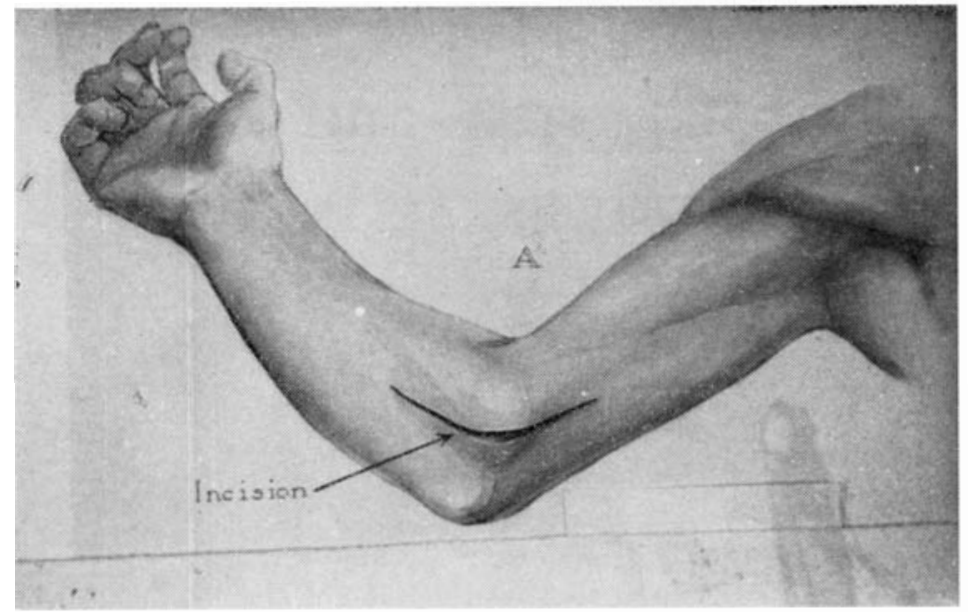

Fig. 1

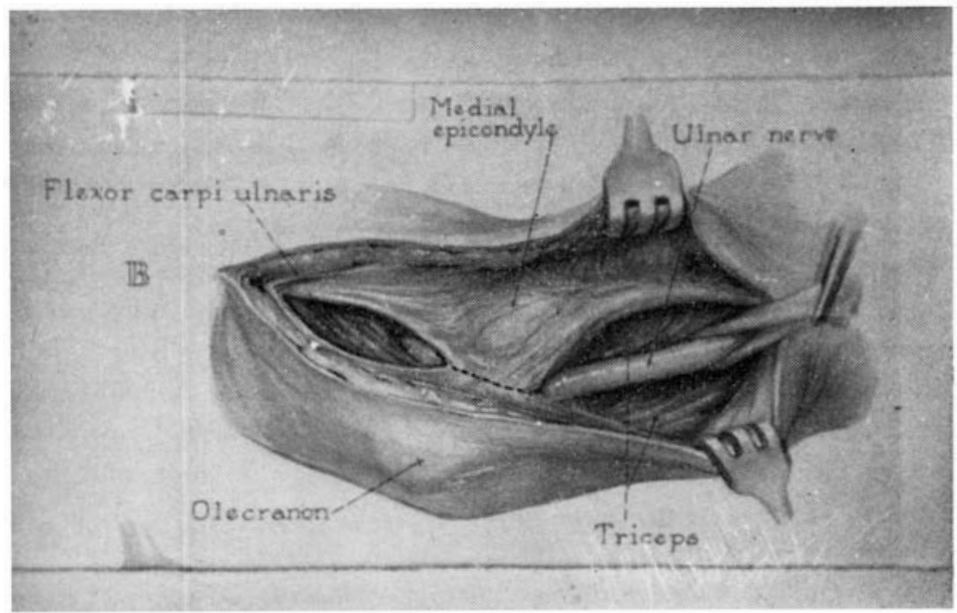

Fig. 2

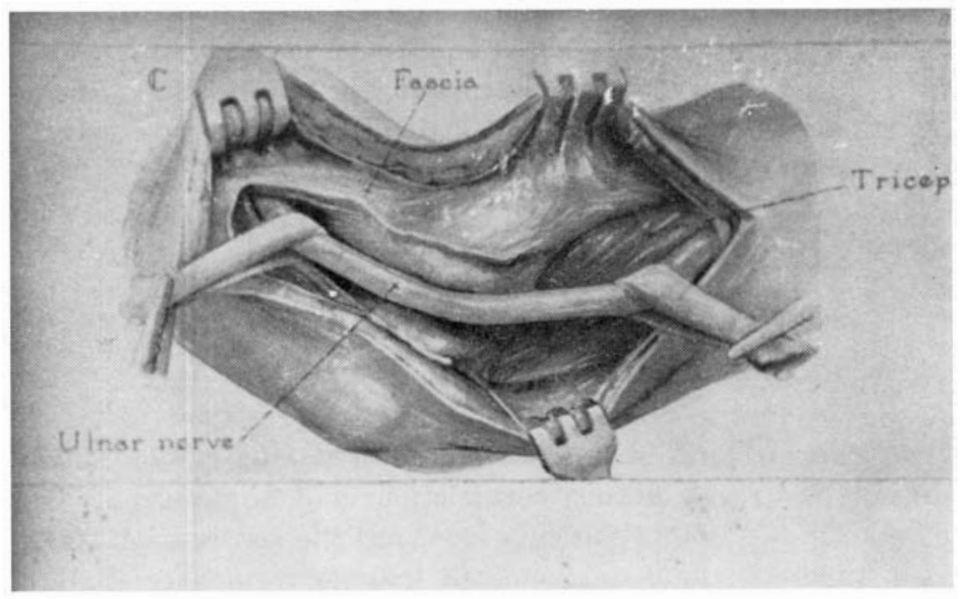

Fig. 3 
TABLE 1

Analysis of 88 patients undergoing decompression of nerve

\begin{tabular}{|c|c|c|c|c|c|c|c|c|c|}
\hline \multirow[b]{2}{*}{ Tyре } & & & & \multicolumn{3}{|c|}{$L E F T H A N D$} & \multicolumn{3}{|c|}{$R I G H T H A N D$} \\
\hline & & & & Male & Female & Total & Male & Female & Total \\
\hline Lepromatous & . & . & . & 13 & 2 & 15 & 16 & 5 & 21 \\
\hline Borderline . . & .. & .. & . & 5 & & 5 & 4 & - & 4 \\
\hline Polyneuritic & & & & 2 & & 2 & 5 & 2 & 7 \\
\hline
\end{tabular}

TABLE 2

Analysis of 24 control patients

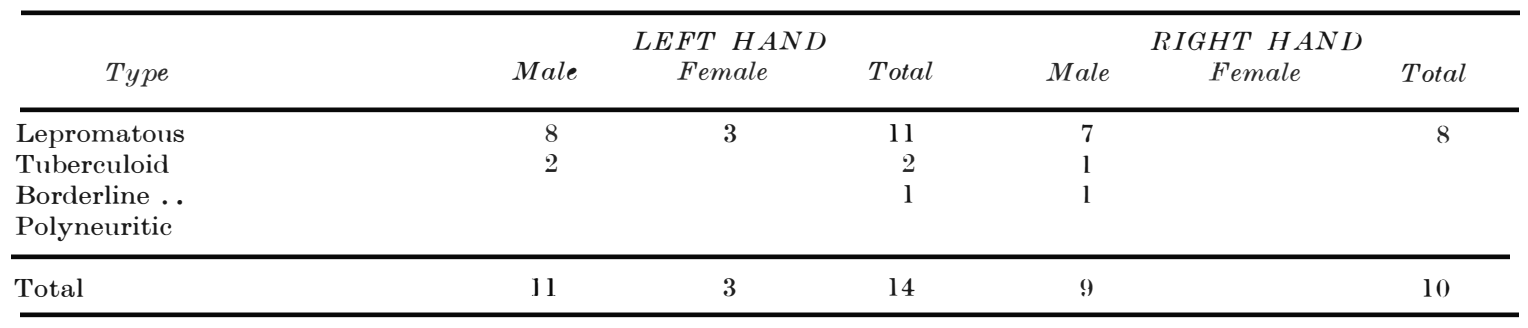

TABLE 3

Analysis of 85 patients with neuritis after decompression

\begin{tabular}{|c|c|c|c|c|c|c|c|c|c|c|}
\hline \multirow{3}{*}{ Type } & \multicolumn{5}{|c|}{ SHORT DURATION (Within 3 months) } & \multicolumn{5}{|c|}{ LONG DURATION (Above 3 months) } \\
\hline & \multicolumn{2}{|c|}{$\begin{array}{l}\text { Non-recurrence } \\
\text { of Neuritis }\end{array}$} & \multicolumn{2}{|c|}{$\begin{array}{l}\text { Recurrence } \\
\text { of Neuritis }\end{array}$} & \multirow{2}{*}{$\begin{array}{l}\text { Total } \\
\text { No. }\end{array}$} & \multicolumn{2}{|c|}{$\begin{array}{c}\text { Non-recurrence } \\
\text { of Neuritis }\end{array}$} & \multicolumn{2}{|c|}{$\begin{array}{l}\text { Recurrence } \\
\text { of Neuritis }\end{array}$} & \multirow{2}{*}{$\begin{array}{l}\text { Total } \\
\text { No. }\end{array}$} \\
\hline & No. & $\%$ & No. & $\%$ & & No. & $\%$ & No. & $\%$ & \\
\hline Lepromatous & 17 & 94.4 & & 5.6 & 18 & 15 & 83.3 & 2 & 1 1. 7 & 17 \\
\hline Tuberculoid & 17 & 100 & 一 & - & 17 & 17 & 100 & - & & 17 \\
\hline Borderline & 2 & 100 & 一 & - & 2 & 5 & 100 & - & - & 5 \\
\hline Total & 39 & 97.5 & 1 & 2.5 & 40 & 43 & 95.6 & 2 & 4.4 & 45 \\
\hline
\end{tabular}

TABLE 4

Analysis of 24 control patients with neuritis

\begin{tabular}{|c|c|c|c|c|c|c|c|c|c|c|}
\hline \multirow{3}{*}{ Type } & \multicolumn{5}{|c|}{ SHORT DURATION (Within 3 months) } & \multicolumn{5}{|c|}{ LONG DURATION (Above 3 months) } \\
\hline & \multicolumn{2}{|c|}{$\begin{array}{c}\text { Non-recurrence } \\
\text { of Neuritis }\end{array}$} & \multicolumn{2}{|c|}{$\begin{array}{l}\text { Recurrence } \\
\text { of Neuritis }\end{array}$} & \multirow{2}{*}{$\begin{array}{c}\text { Total } \\
\text { No. }\end{array}$} & \multicolumn{2}{|c|}{$\begin{array}{l}\text { Non-recurrence } \\
\text { of Neuritis }\end{array}$} & \multicolumn{2}{|c|}{$\begin{array}{l}\text { Recurrence } \\
\text { of Neuritis }\end{array}$} & \multirow{2}{*}{$\begin{array}{c}\text { Total } \\
\text { No. }\end{array}$} \\
\hline & No. & $\%$ & No. & $\%$ & & No. & $\%$ & No. & $\%$ & \\
\hline Lepromatous & 2 & 28.6 & 5 & 71.4 & 7 & 3 & 25 & 9 & 75 & 12 \\
\hline Tuberculoid & & & & & & & & 3 & 100 & 3 \\
\hline Borderline & & 100 & & & 1 & & & 1 & 100 & 1 \\
\hline Polyneuritic & & & & & & & & & & \\
\hline Total & 3 & 37.5 & 5 & 62.5 & 8 & 3 & 18.75 & 13 & 81.25 & 16 \\
\hline
\end{tabular}


TABLE 5

Analysis of 85 patients with sensory loss after decompression

\begin{tabular}{|c|c|c|c|c|c|c|c|c|c|c|c|c|c|}
\hline \multirow{3}{*}{ Type } & \multicolumn{7}{|c|}{ SHORT DURATION (Within 3 months) } & \multicolumn{6}{|c|}{ LONG DURATION (Above 3 months) } \\
\hline & \multicolumn{2}{|c|}{$\begin{array}{c}\text { Sensory } \\
\text { Recovered }\end{array}$} & \multicolumn{2}{|c|}{$\begin{array}{c}\text { Sensory } \\
\text { Stationary }\end{array}$} & \multicolumn{2}{|c|}{$\begin{array}{l}\text { Sensory } \\
\text { Worsened }\end{array}$} & \multirow{2}{*}{$\begin{array}{l}\text { Total } \\
\text { No. }\end{array}$} & \multicolumn{2}{|c|}{$\begin{array}{l}\text { Sensory } \\
\text { Recovered }\end{array}$} & \multicolumn{2}{|c|}{$\begin{array}{c}\text { Sensory } \\
\text { Stationary }\end{array}$} & $\begin{array}{l}\text { Sensory } \\
\text { Worsened }\end{array}$ & \multirow{2}{*}{$\begin{array}{l}\text { Total } \\
\text { No. }\end{array}$} \\
\hline & No. & $\%$ & No. & $\%$ & No. & $\%$ & & No. & $\%$ & No. & $\%$ & No. $\quad \%$ & \\
\hline Lepromatous & 11 & 61 & 6 & 33.3 & 1 & 5.7 & 18 & 3 & 17.6 & 14 & 82.4 & & 17 \\
\hline Tuberculoid & 8 & 47 & 9 & 53 & - & - & 17 & 2 & 11.7 & 15 & 88.3 & & 17 \\
\hline Borderline & - & - & 2 & 100 & - & - & 2 & - & - & 5 & 100 & & 5 \\
\hline Polyneuritic & 1 & 33.3 & 2 & 66.7 & - & - & 3 & 2 & 33.3 & 4 & 66.7 & & 6 \\
\hline Total & 20 & 50 & 19 & 47.5 & & 2.5 & 40 & 7 & 14.4 & 38 & 85.6 & & 45 \\
\hline
\end{tabular}

TABLE 6

Analysis of 24 control patients with sensory loss

\begin{tabular}{|c|c|c|c|c|c|c|c|c|c|c|c|c|c|c|}
\hline \multirow{3}{*}{ Type } & \multicolumn{7}{|c|}{ SHORT DURATION (Within 3 months) } & \multicolumn{7}{|c|}{ LONG DURATION (Above 3 months) } \\
\hline & \multicolumn{2}{|c|}{$\begin{array}{c}\text { Sensory } \\
\text { Recovered }\end{array}$} & \multicolumn{2}{|c|}{$\begin{array}{c}\text { Sensory } \\
\text { Stationary }\end{array}$} & \multicolumn{2}{|c|}{$\begin{array}{l}\text { Sensory } \\
\text { Worsened }\end{array}$} & \multirow{2}{*}{$\begin{array}{c}\text { Total } \\
\text { No. }\end{array}$} & \multicolumn{2}{|c|}{$\begin{array}{c}\text { Sensory } \\
\text { Recovered }\end{array}$} & \multicolumn{2}{|c|}{$\begin{array}{c}\text { Sensory } \\
\text { Stationary }\end{array}$} & \multicolumn{2}{|c|}{$\begin{array}{l}\text { Sensory } \\
\text { Worsened }\end{array}$} & \multirow{2}{*}{$\begin{array}{c}\text { Total } \\
\text { No. }\end{array}$} \\
\hline & No. & $\%$ & No. & $\%$ & No. & $\%$ & & No. & $\%$ & No. & $\%$ & No. & $\%$ & \\
\hline Lepromatous & 2 & 28.6 & 4 & 57.2 & 1 & 14.3 & 7 & - & - & 10 & 83.3 & 2 & 16.7 & 12 \\
\hline Tuberculoid & - & - & - & - & - & - & - & - & - & 3 & 100 & - & - & 3 \\
\hline Borderline & - & 一 & - & 100 & - & - & 1 & - & - & 1 & 100 & - & - & 1 \\
\hline Polyneuritic & 一 & - & - & - & - & - & - & - & - & 一 & - & - & - & - \\
\hline Total & 2 & 25 & 5 & 62.5 & 1 & 12.5 & 8 & - & - & 14 & 87.5 & 2 & 12.5 & 16 \\
\hline
\end{tabular}

TABLe 7

Analysis of patients with paralysis after decompression

\begin{tabular}{|c|c|c|c|c|c|c|c|c|c|c|c|c|c|c|}
\hline \multirow{3}{*}{ Type } & \multicolumn{7}{|c|}{$\begin{array}{l}\text { SHORT DURATION (Within } 3 \text { months) } \\
\text { Recovered }\end{array}$} & \multicolumn{7}{|c|}{ LONG DURATION (Above 3 months) } \\
\hline & $\mathrm{Com}_{1}$ & pletely & Stat & nary & Wor & ned & Total & Com & etely & Stat & onary & Wor & ened & Total \\
\hline & No. & $\%$ & No. & $\%$ & No. & $\%$ & No. & No. & $\%$ & No. & $\%$ & No. & $\%$ & No. \\
\hline Lepromatous & 5 & 71.43 & 2 & 28.57 & - & - & 7 & 4 & 36.36 & 7 & 63.64 & - & - & 11 \\
\hline Tuberculoid & 7 & 63.64 & 4 & 36.36 & - & - & 11 & 1 & 7.14 & 13 & 92.86 & - & - & 14 \\
\hline Borderline & 1 & 100 & - & - & - & - & 1 & 1 & 14.3 & 6 & 85.7 & - & - & 7 \\
\hline Polyneuritic & 2 & 100 & - & & - & - & 2 & - & - & 4 & 100 & - & - & 4 \\
\hline Total & 15 & 71.43 & 6 & 38.57 & - & - & 21 & 6 & 16.7 & 30 & 83.3 & - & - & 36 \\
\hline
\end{tabular}

TABLE 8

Analysis of 12 control patients

\begin{tabular}{|c|c|c|c|c|c|c|c|c|c|c|c|c|c|}
\hline \multirow{3}{*}{ Type } & \multicolumn{6}{|c|}{ SHORT DURATION (Within 3 months) } & \multicolumn{7}{|c|}{ LONG DURATION (Above 3 months) } \\
\hline & $\begin{array}{l}\text { Recovered } \\
\text { Completely }\end{array}$ & \multicolumn{2}{|c|}{ Stationary } & \multicolumn{2}{|c|}{ Worsened } & \multirow{2}{*}{$\begin{array}{c}\text { Total } \\
\text { No. }\end{array}$} & \multicolumn{2}{|c|}{$\begin{array}{c}\text { Recovered } \\
\text { Completely }\end{array}$} & \multicolumn{2}{|c|}{ Stationary } & \multicolumn{2}{|c|}{ Worsened } & \multirow{2}{*}{$\begin{array}{r}\text { Tota } \\
\text { No. }\end{array}$} \\
\hline & No. $\%$ & No. & $\%$ & No. & $\%$ & & No. & $\%$ & No. & $\%$ & No. & $\%$ & \\
\hline Lepromatous & 100 & & & & & & & 14.3 & 5 & 71.4 & & 14.3 & 7 \\
\hline Tuberculoid & & & & & & & & & 3 & 100 & & & 3 \\
\hline Borderline & & & 100 & & & & & & & & & & \\
\hline Total & 50 & & 50 & & & 2 & & 10 & 8 & 80 & & 10 & 10 \\
\hline
\end{tabular}


Sensory Changes (Table 5). In the first group of 40 patients, 20 had complete recovery of sensation, and in the second group of 45, only 7 recovered sensation. Table 6 gives the results for the controls. Decompression thus helps in preventing further episodes of neuritis and damage to the nerves.

Paralysis (Table 7). Of 21 patients with paralysis of the hands of short duration, 15 recovered completely after decompression and 6 remained stationary; of 36 who had paralysis of long duration, only 6 recovered completely and 30 remained stationary. Table 8 gives the results for the controls.

\section{DISCUSSION AND CONCLUSIONS}

From the observations recorded, we agree with Chatterjee (1955) that the neural signs and symptoms of leprosy have a close relationship with the blood supply to the nerves.

\section{SUMMARY}

Relief of pressure on the ulnar nerve by operative section of the constricting fibrous arch just above the heads of origin of the flexor carpi ulnaris is held to account for the good clinical results in 85 patients. Motor paralysis of short duration showed complete recovering, and sensation returned in a smaller proportion of patients.

\section{ACKNOWLED GMENTS}

Our grateful thanks are due to Dr. (Miss) C. Vellut, M.D., Superintendent of the Leprosy Centre, Polambakkam, for encouraging us to publish this paper. We are also grateful to all the para-medical workers and physiotherapists, especially Mr. K. Atchilingam; and to Mr. N. S. Sadagopan for his secretarial help.

\section{BIBLIOGRAPHY}

1. albert Lasierra, P. Tratamiento quirurgico de las lesiones nerviosas periféricas en la lepra (Surgical treatment of peripheral nerve lesions in leprosy. Rev. Clin. española, 51, 376-378 (1953). Abstract from Int. .J. Lepr., 22 (1954).

2. Bose, K. S., ghosh, s. and mukerJee, N. Decompression of nerves in the treatment of leprosy neuritis. J. Ind. Med. Ass., 42, 456-460 (1964). Abstract from Int. J. Lepr., 2 (1965).
3. Banks and Laufman. An Atlas of Surgical Exposures of the Extremities. Philadelphia. W. B. Saunders Co. (1953).

4. BRAND, PAUL w. Prevention of Deformity. VIIth International Congress of Leprology, Tokyo (1958).

5. BULbRING, E. and BURN J. H. Vascular changes affecting transmission of nervous impulses. $J$. Phys., 97, 250-264 (1939).

6. Chala H. J. IGNacio, Cloruro de Tiamina y complejo de vitamina $B$ en el tratamiento de la lepra. Publications of the Institute Federico Lleras Acosta. Reprinted in the Annals of the Society of Biology of Bogota I, 253-284 (1945). (Abstracts from Int. J. Lepr., 14, 4, 1946.)

7. CARAYON, A., BOURREL, P. and LANGUillon, J. Chirurgie de la lèpre, 1964.

8. CHATtERJEe, S. N. The mechanism of neural signs and symptoms of leprosy. Int. .J. Lepr., 23, 1 (1955).

9. CHATterJee, S. N. Mechanism of blister formation in leprosy patients. Int. J. Lepr., 27, 4 (1959).

10. ChatterJee, s. N. Muscular wasting in leprosy and its peculiarities. Int. .J. Lepr., 31, 280-302 (1963).

11. CRUTZ, M. C., ABUEL, J. I. and SAMSON, J. G. Leprosy in India, 5, 51 (1933).

12. CRUTZ, M. C., ABUEL, J. I. and SAMSON, J. G. .J. Philipp. Med. Ass., 11, 474-476 (1931).

13. Dastur, D. K., Antia, N. H. and Divekar, S. C. Int. .J. Lepr., 34, $118-138$ (1966).

14. DASTUR, D. K. Leprosy in India, 39, 107 (1967).

15. GARRETT, A. s. Hyalase injection for lepromatous nerve reaction. Lep. Rev., 27, 61 (1956).

16. GOHEen, R. H. Leprosy in India, 5, 4-5 (1933).

17. HARRIS, J. Criteria for assessing the results of treatment of acute ulnar neuritis. Leprosy in India, 36, 2 (1964).

18. HORAN, J. s. Treatment of lepra reaction andacute neuritis and arthritis with nerve block and intravenous administration of procaine-Prelinary report. Int. .J. Lepr., 17, 3 (1949).

19. IDRISOv, A. S. [Experience with surgery on peripheral nerves in leprosy patients.] Zdravookhr Kazakh, 22, 8-11 (1962). Abstract from Int. J. Lepr., 31, 1 (1963).

20. IOFFE, J. L. The treatment of neuritis in leprosy by means of perineural injections of lidase. 'Learned Notes of the Institute for the Study of Leprosy, 4 (a), 1964.

21. IOFFE, J. L. The surgical treatment of neuritis in leprosy. 'Learned Notes of the Institute for the Study of Leprosy, 4 (a), 1964.'

22. KHer, G. A., RAMU, G., Hussain, F. and Bose, s. Blood supply of the nerves of the upper limb. J. Ind. Med. Ass., 36, 395-396 (1961).

23. MARINO BECHELli et al. A vitamina B no tratamento das nevrites leprosas (Vitamin B in the treatment of leprotic neuritis). Rev. Bras. Leprol., 7, Special No., 257-264 (1939). Abstract from Int. J. Lepr., 13, 4 (1945).

24. RAMANUJAM, K. A note on the use of intra-neural corticosteroids in acute leprous neuritis. Leprosy in India, 36, 4 (1964). 
25. HINGSON, ROBERT, A. et al. Preliminary study of the hypospray for parenteral therapy in its relation to the management of leprosy. Int. $J$. Lepr., 16, 2 (1948).

26. SEPHA, G. C. and SHARMA, D. R. Intraneural cortisone and priscol in treatment of leprosy. Leprosy in India, 36, 4 (1964).

27. Selveira, L. M. Tratamento Cirurgico das neuritis. Rev. Bras. Leprol., 12, 3-9 (1944).

28. ShaRpey-SChaEfer, E. P. and WAllaCe, J. Brit. Med. J., 2, 304-307 (1942).

29. THANGARAJ, R. H. and ThANGARAJ, s. AROJINI (mRs.). Treatment of Acute Leprotic Neuritis. Lep. Rev., 31, 4 (1960).
30. vaidyanathan, E. P. Rehabilitation of Leprosy Patients-Paper-Fifth Biennal Meeting of Indian Association of Leprologists, January, 1962, Hyderabad.

31. vespoli, T. Contribucao ao tratamento das nevrites na lepra. Nevrite leprotica. Rev. Bras. Leprol., 8, Special No., 75-83 (1940). Abstract from Int. J. Lepr., 13, 4 (1945).

32. Wilkinson, F. F. and BRusco, c. M. Acción de un inhibidor de la anhidrasa carbonica en las neuritis hansenianas (Activity of carbonic anhydrase as inhibitor in leprous neuritis). Leprologica, 1, 75-76 (1956). Abstract from Int. J. Lepr., 25, 4 (1957).

33. WYNN PARRY, c. B. Rehabilitation of the hand, 74-92. 